\title{
The Role of Open and Distance Learning in the Implementation of the Right to Education in Zambia
}

\author{
Richard Siaciwena and Foster Lubinda \\ Zambia
}

\begin{abstract}
As a member of the United Nations, Zambia is committed to the observance of human rights enshrined in the Universal Declaration of Human Rights of 1948. This is evidenced, among others, by the fact that Zambia is a signatory to the Convention on the Rights of the Child and the African Charter on the Rights and Welfare of the Child. Zambia has a permanent Human Rights Commission that includes a subcommittee on child rights whose focus is on child abuse and education. Zambia also has a National Child Policy and National Youth Policy whose main objectives are to holistically address problems affecting children and youth. This paper focuses on the progress and challenges currently facing Zambia and the role of open and distance learning in addressing those challenges.
\end{abstract}

Keywords: open and distance learning; policy; human rights; teacher training; basic education

\section{Introduction}

As a member of the United Nations, Zambia is committed to the observance of human rights enshrined in the Universal Declaration of Human Rights of 1948. This is evidenced, among others, by the fact that it is a signatory to the Convention on the Rights of the Child and the African Charter on the Rights and Welfare of the Child. The country has a permanent Human Rights Commission, which has a subcommittee on child rights, and whose main concerns focus on child abuse and education. Zambia also has a National Child Policy and National Youth Policy whose main objectives are to holistically address problems affecting children and youth.

In this context, the Zambian Government recognizes education as a basic human right that is vital for personal and societal development, in general, and for achieving the Education for All targets and the Millennium Development Goals, in particular. The National Policy on Education: Educating Our Future and other policy documents reaffirm the Zambian Government's commitment to providing education as a human right and its conviction that education and training are necessary pre-conditions for human and economic development (Government of Zambia, 1996; Ministry of Education, 1996).

The implementation of the right to education necessarily requires a firm policy framework. One of Zambia's key educational policy objectives is to provide free basic education to all children, 
which is responsive to girls, rural children, children with special educational needs, orphans, and other vulnerable groups (Ministry of Education, 1996).

Accordingly, various strategies and institutional structures have been developed to ensure that access to, and participation and benefit in, the education system is available to all. This article describes and analyzes policies that promote provision of schooling at sustainable levels of quality and gender balance for children and young people (up to 18 years) in accordance with the convention on the Rights of Children. It discusses achievements and challenges in educational provision, in general, and in the use of open and distance learning in particular. It ends with an assessment of the future role of open and distance learning in increasing access to education and improving quality within the context of socio-economic development policies, and as a means of implementing the right to education in Zambia.

\section{Policy Context}

The National Policy on Education, Educating Our Future, which sets the principles for the development of education in Zambia, states that education in Zambia is intended to serve individual, social, and economic well-being, and to enhance the quality of life for all (Ministry of Education, 1996). Noting that the long standing goal of education in Zambia has been that every child who enters school in Grade 1, should be able to complete Grade 9, the national policy on education proposes structural changes in the formal school system that aim to upgrade every primary school to complete basic school status and to offer the full range of basic education from Grade 1 to Grade 9 (primary and junior secondary cycle).

The targets which the Ministry of Education has set for achieving universal primary education were 100 percent of 7-13 year-olds to be in Grades 1-7; 50 percent of Grade 7 pupils (14 yearolds) to progress to Grade 8 by 2005; and 100 percent of 7-15 year-olds to be in Grades 1-9 by 2015.

The policy also provides for the expansion of high school education, and pays special attention to establishing additional facilities for girls (Ministry of Education, 1996). In addition, the policy document proposes strategies for strengthening and expanding higher education and that "the Ministry will promote open learning, lifelong education, and a wide variety of mechanisms for continuing and distance education" (Ministry of Education, 1996, p. 80). One of the strategies in the National Policy on Education is to integrate the provision of continuing and distance education into the mainstream of the Ministry of Education planning processes.

Zambia's National Policy on Education also recognizes the urgent need for a great increase in the number of trained teachers for lower and middle basic classes. One of the proposed strategies for bringing about this increase is providing initial teacher preparation through distance education programmes (Ministry of Education, 1996). The policy further emphasizes the need to provide inservice training opportunities, some of which should be school-based, and states in this regard that "a suitable arrangement would be the integration of decentralized college-based development of materials into the framework of a national programme of distance education for serving teachers” (Ministry of Education, 1996, p. 117).

The Poverty Reduction Strategy Paper (2002 - 2004) provided for the expansion of educational provision at all levels of the Zambian education system. One of its strategies was to promote and integrate the use of Information and Communication Technologies (ICT) at all levels and in all modes of the education delivery systems. It emphasizes the need to use distance learning 
strategies and other modes of delivery, such as ICT, to increase access for out-of-school youths and adults, and for improving quality and increasing access to high school education.

In the context of the National Policy on Education and the Poverty Reduction Strategy Paper, the Ministry of Education developed a Strategic Plan: 2002-2007. The main priorities of this strategic plan includes improved access, gender equity, and quality in basic education (Grades 19); improved quality and efficiency in high schools and tertiary education; development of relevant skills and enhanced learning achievement by all learners; and management/ mitigation of HIV/AIDS.

Clearly, the policy documents cited above are very closely related to, and in line with, the Education For All targets and the Millennium Development Goals, and are evidence of the Government's commitment to implementing the right to education.

Consequently, strategies and mechanisms have been developed to increase school places for orphans and vulnerable children, to address the effect of poverty, to serve children with special educational needs, and to mitigate HIV/AIDS. In addition, the policy of free education was introduced in 2002 (Ministry of Education, 2003).

Largely as a result of these measures educational provision, particularly at basic education level, has improved markedly during the last five years, as evidenced by the following (see Government of Zambia, 2006, Ministry of Education, 2006a).

- Enrolments in Grades 1-7 and Grades 8-9 have increased at an average of 9 percent annually since 2000. At the primary school level, lower and middle basic (Grades 1-7), the net enrolment ratio was 95.58 (95.28 percent for male and 95.88 percent for female) in 2005. The net enrolment ratio for Grades 1-9 was 93.46 percent in the same year.

- Since 2000, enrolments at high school/ secondary level averaged 10 percent per year. In 2005, the net enrolment ratio at this level was 21.54 percent at national level.

- In 2005 completion rates for Grade 7 increased by 13.3 percent, while at the Grade 9 level it increased by 11.9 percent. For Grades 1-7 (primary) the national completion rate was 81.6 percent in that year. In the same year the national completion rate for Grade 9 was 43.1 percent.

- Drop out rates have declined over the years. At the basic education level, the drop out rate went down from 4.6 percent in 2000 to 2.5 percent in 2005. At the high school level, it remained at the same level, approximately 2 percent, from 2000 to 2005.

- The retention rates have been fluctuating for Grade 5, but in general have been above 70 percent.

- In 2005, completion rates for Grade 7 increased by 13.3 percent, while at the Grade 9 level it increased by 11.9 percent. For Grades 1-7 (primary) the national completion rate was 81.6 percent in 2005. In the same year, the national completion rate for Grade 9 was 43.1 percent. 
Nonetheless, despite the above improvements, the effects of the past inadequacy of educational provision, due to the negative effect of the economic decline of the 1980s and 1990s, are still evident:

- An estimated 22 percent of the population has had no formal education.

- Of the total population, only 25 percent have completed lower primary, 27 percent upper primary, 13 percent junior secondary, and 11 percent senior secondary.

- Only 2 percent of Zambia's population has completed a Bachelor's degree or above.

- Twenty-four percent of females never had any formal education, compared to 20 percent for males.

- More males attained secondary school level or above than the females (Government of Zambia, 2006b).

Against this background, the Government of Zambia has to address some challenges in order to ensure that the right to education is fully implemented.

\section{Issues and Challenges}

Zambia has a bottom-heavy demographic structure, in which an estimated 46.5 percent of the population is below the age of 15. In 2006, young people aged 25 years and less accounted for 68 percent of the estimated total population of 11.7 million, with an annual population growth rate of 2.9 percent (Government of Zambia, 2006). Zambia, therefore, faces a challenge of expanding education and training provision to respond to the needs of the growing number of children and large numbers of young people.

The formal education system is characterized by a pyramidal structure, with selection hurdles at various levels, which tend to limit access to higher levels. Although the progression rates have improved in recent years, they are comparatively low. For example, in 2005 the overall transition rate for Grades 7-8 was 56.33 percent, and 41.20 percent for Grades 9-10 (Ministry of Education, 2006).

The comparatively high levels of poverty, estimated at 68 percent of the population (and much higher in rural areas), along with HIV/AIDS, have had a negative impact on the provision of education. It is estimated that the national prevalence rate of HIV/AIDS is about 16 percent of the 15-49 years age group. About 8 percent of boys and 17 percent of girls age $15-24$ are living with HIV (Government of Zambia, 2006). As a result, there are large and increasing numbers of orphaned and vulnerable children, a large proportion of which have no access to education. It was recently estimated that the number of orphans in Zambia ranges from 750,000 to 1.2 million, of which 75 percent are HIV orphans (Government of Zambia, 2006).

The negative effects of poverty and HIV/AIDS include high dropout rates, poor performance, poor attendance (because children are engaged in income-generating activities to supplement family income or tending to sick family members), and the inability of learners to achieve their full potential because they are malnourished (Ministry of Finance and National Planning, 2002). 
The Government of Zambia, therefore, faces the challenge of increasing access to vulnerable children; improving the retention rate for girls and ensuring they complete the education system and actually benefit from it; and increasing school places for the 7 year old age group. It also must address the issues surrounding the shortage of qualified teachers, the challenge of improving the quality, relevance, and delivery of the curriculum; and the provision of more teaching and learning materials to match the increased enrolment. The enormity of the task necessarily requires a diversification of modes of educational delivery such as open and distance learning.

\section{The Role of Open and Distance Learning}

The role of open and distance learning in the implementation of the right to education is being described and analyzed in the context of the United Nations Convention on the Rights of the child (UNCRC) partly because the Revised National Child Policy in Zambia defines a 'child' as any person aged 18 years and under. Therefore, the article describes the use of open and distance learning at basic and high school levels. Reference will also be made to the role of open and distance learning in widening access to education to the $18-24$ year age group. This is because one of the greatest challenges facing the Government of Zambia faces is that it must respond to educational needs of the children and the youth who constitute the majority of the Zambian population.

The article also describes the role of open and distance learning in teacher training. This is because of the symbiotic relationship between expanding learning opportunities and the demand and supply of teachers. This relationship is summed up in Eastern Washington University's (2005) presentation of 'Children's Educational Rights':

- I have the right to an education that meets my needs as a whole person - not merely the needs of society or the economy.

- I have the right to a school building in good condition, to a safe learning environment, and to adequate books and supplies.

- I have a right to teachers who know how to teach kids - not just programs.

- I have a right to teachers with the knowledge, authority, and responsibility to meet my needs as an individual learner.

- I have the right to be motivated and challenged to become a lifelong learner (see http://www.ewu.edu/x14913.xml).

Since its political independence in 1964, open and distance learning in Zambia has been used to increase access to and improve the quality of education at all levels of the education system.

(a) Open and distance learning for basic education: The Directorate of Open and Distance Education of Zambia's Ministry of Education has developed alternative basic education programmes at lower basic (Grades 1-4), middle basic (Grades 5-7), and upper basic (Grade 8) levels. The alternative lower and middle basic education programmes are delivered to learners countrywide using Interactive Radio Instruction in community supported learning centres. 
The programme aims to reach out-of-school children who have no basic education, nor the ability to access the formal school system due to inadequate provision or insufficient facilities, poverty, distance to the nearest formal/ government school, increasing parental disinterest in school education, and the impact of HIV/AIDS.

The Interactive Radio Instruction (IRI) programme was launched in July 2000 as a pilot project catering for Grade 1 learners at 22 IRI learning centres. There are currently two main types of IRI schools: pure or original type of centres, which depend entirely on radio lessons and mentors, and community schools using IRI methodology wherein children learn by following a radio lesson under the supervision of a mentor.

Community schools are more like conventional schools established; they are owned, financed, and operated by communities for their own children, particularly children in special need such as orphans (above all, girl-orphans). Nearly all community schools are small, working according to their own curriculum and responding flexibly to the needs of poor, by-passed, and disadvantaged children (Kelly, 1998).

Table 1 shows the number of learners the majority of whom are in Grade 1 . It has been noted that this has been the trend since 2000 when the programme was launched.

Table 1. Distribution of Learners by Age and Grade 2006

\begin{tabular}{lllllll}
\hline $\begin{array}{l}\text { Learners } \\
\text { (Grade and age) }\end{array}$ & Total & $\%$ & $\begin{array}{l}\text { Grade } \\
\text { specific age }\end{array}$ & $\begin{array}{l}\text { Below } \\
\text { recommended }\end{array}$ & $\begin{array}{l}\text { Above } \\
\text { recommended }\end{array}$ & Missing \\
G1 (7 yrs) & 35,633 & $44 \%$ & $33 \%$ & $19 \%$ & $46 \%$ & $2 \%$ \\
G2 (8 yrs) & 18,184 & $22 \%$ & $22 \%$ & $11 \%$ & $64 \%$ & $3 \%$ \\
G3 (9 yrs) & 12,036 & $15 \%$ & $14 \%$ & $7 \%$ & $76 \%$ & $3 \%$ \\
G4 (10 yrs) & 7,760 & $10 \%$ & $14 \%$ & $8 \%$ & $73 \%$ & $5 \%$ \\
G5 (11 yrs) & 4,834 & $6 \%$ & $11 \%$ & $8 \%$ & $78 \%$ & $3 \%$ \\
G6 (12yrs) & 2870 & $4 \%$ & $10 \%$ & $7 \%$ & $5 \%$ \\
\hline
\end{tabular}

Source: 2006 IRI Statistical Report (Ministry of Education, 2006b)

Table 1 shows that many learners in every grade are over the recommended age. This implies that there could be learners who had left school or had no opportunity to enter school when they were of the right age.

The creation of IRI schools is a partnership between the Ministry of Education and the community, and IRI centres and community schools depend on the community and parents and other external sources for mentors or teachers, materials, and learning venues (Ministry of Education, 2006b).

The major supporting organizations of the IRI centres are community members (29\%), local community-based organizations (6\%), international non-governmental organizations (24\%), churches (12\%) and the government (13\%). The rest are individuals and affiliate organizations (Ministry of Education, 2006b).

The programme has been expanding rapidly since its inception as evidenced by the increase in the number of schools using IRI radio broadcasts from 893 in 2005 to 1,058 in 2006, and the number of community schools adopting IRI methodology, which increased from 338 in 2005 to 497 in 
The Role of Open and Distance Learning in the Implementation of the Right to Education in Zambia Siaciwena \& Lubinda

2006. The number of learners (out-of-school children) also increased from 56,233 in 2005 to 81,324 in 2006, reflecting a 44 percent increase (Ministry of Education, 2006b, p. 12).

The IRI programme has contributed to the implementation of the Zambian's 'right to education' and addresses some of the educational challenges:

- In 2005 the IRI centres constituted 12.30 percent of the number of schools offering basic education - i.e., 893 IRI centres out of a total 7,256 schools offering basic education. This is a significant contribution when one considers the fact that a number of the 2,318 community schools in that same year used IRI radio broadcasts.

- IRI radio broadcasts have helped to improve the quality of education in community schools. A study conducted in 2006 "indicates that community schools adopt IRI . . . to supplement the teaching materials and that IRI assists untrained teachers in the community schools to manage their lessons adequately" (Ministry of Education, 2006b, p. 12).

- The IRI programme is promoting equity and equality in educational provision. Since its launch in 2000, there are more IRI schools in rural areas as compared to urban areas. Between 2005 and 2006, nearly 70 percent of IRI schools were located in rural areas. The remainder are located in urban and peri-urban areas. There is a balanced gender distribution between boys and girls, which was 50.2 percent and 49.8 percent respectively in 2006 (Ministry of Education, 2006b). Equally important is that the number of both single and double orphans accessing basic education through the IRI programmes increased from 18,880 (36\%) in 2005 to 27,481 (35\%) in 2006 (Ministry of Education, 2006b).

- It is contributing to the overall increase in enrolments at basic education level.

- It enables learners to initiate and restart basic education, giving learners a second chance to pursue basic education. The 2006 data indicate that 93 percent of the children enrolled were between 5-15 years. The remainder were either adult learners or under age learners (Ministry of Education, 2006b).

- It has provided a model for building partnerships in the provision of basic education, in general, and in the area of open and distance learning in particular.

The success of the IRI programme has been conditioned by a number of factors. First, it targets children that are not in government schools for various reasons. Though government school education is free, there are other 'hidden costs' involved that tend to inhibit the children from enrolling in these schools (i.e., the cost of exercise books, pens, and travel to school). The IRI programme appears to be the best alternative for children that are very vulnerable, especially the orphans (Ministry of Education, 2006b).

Second, the programme is receiving support from communities. In 2006, for example, many centres and community schools benefited from local communities in terms of construction of better permanent shelters.

Third, there is support from Community Radio Stations. In 2006, six Community Radio Stations in Zambia promoted and broadcast the IRI programme. 
Although the IRI programme has, in recent years, become more visible and widespread, the use of open and distance learning at secondary school level has a longer history, dating back to independence, in 1964.

(b) Secondary level distance education: In the early1970s, the Zambia College of Distance Education (ZACODE) (formerly National Correspondence College) began offering two variants of open and distance learning:

- Directly enrolled adult students studying for junior secondary or General Certificate of Education (GCE) “O” levels (senior secondary school equivalent). In the early 1990s, there were 30,000 such students enrolled.

- Recent primary school leavers in "Open Secondary Classes," who studied in supervised groups at various centres through out Zambia. In the mid 1990s, approximately 19,000 students were enrolled in these study groups at over 250 centres.

The programme virtually ground to a halt in the 1990s, however, due to a number of problems that affected ZACODE, including inadequate funding, which resulted in materials production difficulties and shortages of learning materials and equipment. Other problems were costly postage, large class sizes in open secondary centres, lack of qualified staff and cumbersome administration systems (Tate, 1990).

Zambia's Ministry of Education, through its Directorate of Open and Distance Education has now revived the distance secondary education programme. Print-based self-instructional materials and learner support systems have been developed for the Alternative Upper Basic (equivalent to junior secondary) and Alternative High School (senior secondary) Programmes.

The programmes are targeting potential learners of all age groups who cannot access upper basic or high school education through the conventional school system. The programmes will initially comprise Grades 8 (first grade of junior secondary) and Grade 10 (first grade of senior secondary) due to the high demand at these levels.

The programmes are designed to make efficient use of the existing education infrastructure and to partner with the private sector in the use of technologies. The Alternative Upper Basic Education Programme, launched in March 2006 on a pilot basis, will be conducted in established basic schools, schools for continuing education, and other suitable institutions that may be used in the afternoons for tutorial sessions, which will support the printed materials. The pilot phase has targeted 3,000 learners in 60 learning centres across Zambia. Learning materials, registration forms, and other learner support documents and records, have been distributed to all pilot centres. Registration of learners took place between February and March 2006.

The Alternative High School Programme will be conducted in existing learning centres, such as high schools and other education facilities where learners will learn independently using high quality, interactive teaching and learning materials and may benefit from the offerings broadcasted on digital satellite television and include mathematics, commerce, English, history, and geography. Multichoice SchoolNet Africa, in collaboration with Zambia's Directorate of Open and Distance Education, aims to supply digital satellite television decoders and videocassette recorders to all the high schools in the country. 
ZACODE is responsible for the development of materials, which are being piloted in Zambia's nine provinces. The Curriculum Development Centre has reviewed the materials. The pilot phase (beginning with Grade 10) targets 1,000 learners in 20 learning centres.

(c) Open and distance learning opportunities for high school leavers: The University of Zambia offers degree programmes to both working adults and high school leavers. During the 2006 academic year, young people ages 18-24 constituted approximately 10 percent of the total distance education enrollment at the university. This is significant when one considers that in the recent past university policy restricted distance learning programmes to people of 25 years and above.

In theory, therefore, it is possible for a child to complete most of their education by open and distance learning. The system also makes it possible for learners to move from one mode of learning to the other, that is, from the conventional system to distance learning and vice versa.

(d) Open and distance learning for teacher upgrading: In accordance with the provisions of various policy documents, in 2001 the Ministry of Education launched the 'Primary Teachers' Diploma in Distance Learning' (PTDDL) which is being delivered by the In-service Teachers' College.

The introduction of the diploma in distance learning was in response to the Ministry of Education's desire to retain highly motivated schoolteachers by upgrading their qualification and which subsequently improves the quality of basic education as provided for in the national policy on education.

Most current primary teachers hold a Primary Teacher's Certificate. Before the introduction of the PTDDL programme, the most common way for teachers to upgrade their status was to earn a secondary diploma, which allowed them to teach Grades 8 and 9. As a result, Grade 1-7 teachers who were committed to professional development were leaving the Grade 1-7 classes as they improved their status. The PTDDL programme allowed teachers to obtain the same status as those who earn the secondary diploma, while they continue to use their talents in Grades 1-7.

At the same time that the Ministry of Education saw the need to retain highly motivated Grade 17 teachers, it was rolling out new curricula. The PTDDL programme was seen as a way of providing teachers with a deeper understanding of new content and methodologies.

In 2002, a total of 1,973 learners graduated from the pilot phase. The PTDDL programme was extended to cover all districts in all provinces across Zambia. The second intake of 4,036 students (under the expanded programme) was enrolled in 2003, the majority of which successfully completed the programme. The third cohort of 4,420 students, was enrolled in 2006 (Siaciwena, Trewby, \& Anderson, 2005; Swazi, 2006).

Open and distance learning was chosen to capture as many teachers as possible, because offering the programme as a residential course would have been counterproductive. First, the colleges of education would not have been able to accommodate large numbers of teachers. Indeed, even if the colleges had the capacity, residential education would have removed teachers from their classrooms for extended periods.

The PTDDL programme is contributing a great deal to the upgrading of teachers at primary school level. More than three quarters (76.8\%) of those who enrolled in the programme in 2003 have successfully completed it. 


\section{An Assessment of the Future Role of Open and Distance Learning in Implementing the Right to Education}

The rising demand for education at all levels of the education system necessitates expansion of open and distance learning provision. The Government of Zambia has committed itself to the development of open and distance learning in its policies within the context of which structures, systems and human capacity development programs to improve the planning and development and delivery of open and distance learning have been developed.

However, a number of studies (see Tate, 1990; Siaciwena, et al., 2005; Commonwealth of Learning, 2005) have identified a number of constraints on the development of this mode of educational delivery the main ones being the following:

(a) Political support and legitimacy: Many educational policy-makers, planners, and parents reported to be skeptical about the legitimacy and quality of open and distance learning provisions on grounds that it does not and cannot offer the same quality as conventional, on-campus education.

(b) Policy issues: Despite some policy provisions in various government documents, Zambia lacks a national policy on open and distance learning to guide the development and implementation of programmes at national and institutional levels.

(c) Inadequate human capacity: Lack of infrastructure and professional competence in open and distance learning is a significant barrier. There is a shortage of qualified staff required for guiding and influencing the development of distance education policies, and for planning, developing, managing, and evaluating distance education programs.

(d) Inadequate funding: Partly because of inadequate political support open and distance learning institutions in Zambia lacks financial resources. For example, in 2006 the Directorate of Distance and Open learning, which administers all open and distance learning activities in the Ministry of Education, received 0.2 percent of the total Ministry budget.

(e) Course design and development: Due to a shortage of skilled or trained staff, open and distance learning institutions lack systematic and needs-based design and development of course materials.

( $f$ ) Delivery media: There is a limited range of media used in open and distance learning. Most programs use predominantly print-based or radio-based materials without any support media or materials.

(g)ICT infrastructure: Zambia has an underdeveloped information and communication infrastructure. Consequently, open and distance learning institutions lack effective delivery and support services and systems. Currently, open and distance learning programmes are predominantly print-based or radio based, and help remediate this situation.

(h) Learner support: Most of the institutions do not have well-designed learner support systems for their open and distance learning programmes. Instead, they depend heavily 
on face-to-face teaching during residential school sessions without any institutionalized learner support systems.

(i) Quality assurance: Almost invariably open and distance learning institutions lack effective quality assurance systems. They do not have adequate monitoring, research and evaluation base that is needed to support informed policy choices. Therefore, there is insufficient information on the performance of programmes and this raises doubts about their quality and tends to reinforce negative attitudes towards open and distance learning.

(j) Sustainability: Some open and distance learning programmes have been heavily depended on donor funding and are not sufficiently integrated into the mainstream education systems. For example, the IRI is seen as a project with financial and technical support from USAID, through the educational development centre. This raises questions about sustainability. ZACODE virtually stopped offering secondary distance learning courses when the Germany Adult Education Association (DVV) technical and financial assistance program expired in the early 1990s.

\section{Conclusion}

The rising demand for education at all levels of Zambia's education system necessitates expansion of its open and distance learning provision. The Government of Zambia has committed to the development of open and distance learning in its policies within the context of which structures, systems, and human capacity development programs, to improve the planning and development and delivery of open and distance learning have been developed teacher upgrading.

Its development, however, is constrained by a variety of factors. In general, the design of distance programmes does not sufficiently provide for effective operational systems such as administrative support, course development, delivery, and student support, assessment, monitoring, and evaluation. There is an urgent need to, among other things:

- Provide training in all aspects of open and distance learning through short courses and degree programmes.

- Develop human and infrastructure resource capacity to plan, design, develop, manage, and evaluate open and distance learning systems and programmes.

- Periodically evaluate open and distance learning programmes to improve their quality and ensure that they are responsive to emerging needs.

- Continually review the organizational arrangement and management of open and distance learning programmes in educational institutions to improve coordination, interinstitutional collaboration, operational efficiency and effectiveness.

- Develop quality assurance framework and strategies for open and distance learning.

- Establish and maintain relationships and partnerships with relevant private and public non-educational institutions involved in open and distance learning and information and communication technology development. 
The Role of Open and Distance Learning in the Implementation of the Right to Education in Zambia Siaciwena \& Lubinda

- Develop human resource and institutional capacity to develop and produce quality open and distance learning materials.

- Establish a national consortium for joint course development and sharing of the national open and distance learning networks and facilitating organization of open and distance learning programs countrywide (Commonwealth of Learning, 2005).

\section{References}

Commonwealth of Learning (2005). Zambia Teacher Education Strategy: Final report. Vancouver: Commonwealth of Learning.

Government of Zambia (1996). Investing in Our People: Integrated Education Sector Investment Programme (ESIP) policy framework. Lusaka: Government of Zambia.

Government of Zambia (2006). Fifth National Development Plan 2006-2010. Lusaka: Government of Zambia.

Kelly, M. J. (1998). Primary Education in a Heavily Indebted Poor Country: The case of Zambia in the 1990s. Unpublished Report for OXFAM and UNICEF, October, 1998.

Eastern Washington University (2005). Children's Educational Rights. Eastern Washington University website. Retrieved January 29, 2008 from: http:www.ewu.edu/x14913.xml

Ministry of Education (1996, May). Educating Our Future: National Policy on Education. Lusaka: Ministry of Education.

Ministry of Education (2003). Strategic Plan: 2003-2007. Lusaka: Ministry of Education.

Ministry of Education (2006a). Educational Statistical Bulletin. Lusaka: Ministry of Education.

Ministry of Education (2006b). 2006 IRI Statistical Report. Lusaka: Ministry of Education.

Ministry of Finance and National Planning (2002). Poverty reduction strategy paper (2002 2204). Lusaka: Ministry of Finance and National Planning.

Siaciwena, R., Trewby, R., \& Anderson, D (2005). Evaluation of the Primary Teachers’ Diploma by Distance Learning. Unpublished Report prepared for Zambia’s Ministry of Education. Lusaka: Ministry of Education.

Swazi, H. (2006). Report to the National Coordinating Committee of the Primary Teachers' Diploma by Distance Learning, May 22, 2002. Lusaka: Ministry of Education.

Tate, O. (1990). Distance Education in Zambia. Vancouver: Commonwealth of Learning.

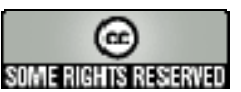

